\title{
Biotechnological Properties of Sponges from Northeast Brazil: Cliona varians as a Biocatalyst for Enantioselective Reduction of Carbonyl Compounds
}

\author{
Valéria B. Riatto, ${ }^{\circledR *, a, b, c}$ Mauricio M. Victor, ${ }^{a, b, c}$ Jaqueline F. Sousa ${ }^{a, b, c}$ and \\ Carla Menegola ${ }^{d}$ \\ ${ }^{a}$ Departamento de Química Orgânica, Instituto de Química, \\ Universidade Federal da Bahia, 40170-115 Salvador-BA, Brazil \\ ${ }^{b}$ Instituto Nacional de Ciência e Tecnologia (INCT) em Energia e Ambiente, \\ Universidade Federal da Bahia, 40170-115 Salvador-BA, Brazil \\ ${ }^{c}$ Centro Interdisciplinar de Energia e Ambiente (CIENAM), \\ Universidade Federal da Bahia, 40170-115 Salvador-BA, Brazil \\ ${ }^{d}$ Centro de Estudos Costeiros, Limnológicos e Marinhos (CECLIMAR), \\ Universidade Federal do Rio Grande do Sul, Campus Litoral Norte, 95625-000 Imbé-RS, Brazil
}

\begin{abstract}
To research the potential ability of whole marine sponges to act as biocatalysts, this paper describes for the first time the employment of whole Cliona varians sponge in the stereoselective reduction of prochiral $\alpha$-keto esters and isatin to the corresponding chiral alcohols. The addition of D-fructose, D-glucose or sucrose remarkably increased the conversion ratios and stereoselectivities by this marine sponge. Furthermore, in the presence of D-glucose and D-maltose, the reduction of isatin by $C$. varians afforded the corresponding 3-hydroxyindolin-2-one with high conversions (85$90 \%$ ) and good enantioselectivities (60-74\%). These results showed that the marine sponge presents great potential to be used as biocatalyst for stereoselective reduction of carbonyl compounds.
\end{abstract}

Keywords: $\alpha$-keto-esters, isatin, biotransformations, marine sponge, Cliona varians

\section{Introduction}

Biotransformation of exogenous substrates have been widely studied and used to prepare chiral compounds. The use of enzymes in catalytic reactions, such as asymmetric reduction of prochiral ketones, is one of the most important and practical reaction for producing chiral alcohols, which can be transformed into various functionalities, to synthesize industrially important chemicals such as pharmaceuticals and other commercial products. ${ }^{1,2}$

The utilization of biocatalytic systems have got benefits of economically viable, ecologically favorable and more sustainable than current chemical technologies, due to their inherent advantages of higher selectivity, milder conditions and comparatively cheaper resources. ${ }^{3}$ However, a limiting factor of use of enzymes is their specificity towards the substrate. ${ }^{4}$ Therefore, searching for new enzymes from easily available natural sources is an important task in the field of asymmetric organic synthesis.

*e-mail: vriatto@ufba.br
In recent years, there are several reports about the possibility of using parts of fresh plants tissue as biocatalysts, since different oxidoreductases and the cofactor regeneration system are present in the plant cell. ${ }^{5}$ Moreover, application of comminuted tissue of ripe vegetable roots in biotransformations, instead of isolated enzymes, is possible due to the group of enzymes excreted to extracellular medium that are able to accept xenobiotic substrates. ${ }^{6}$

Several vegetable species from our Brazilian biodiversity were investigated as biocatalysts in different organic reactions, such as: cushcush (Dioscorea trifida L.) and cactus (Opuntia ficus-indica (L.) Miller), ${ }^{7}$ manioc (Manihot esculenta), ${ }^{8}$ passion fruit (Passiflora edulis) ${ }^{9}$ and sugar cane (Saccharum officinarum).${ }^{10}$ However, Brazilian marine biodiversity remains practically unexplored in the search for new biocatalysts systems.

Sponges (phylum Porifera) are the most primitive multicellular animals, which have existed for 700-800 million years, demonstrating relatively little differentiation and tissue coordination. ${ }^{11}$ To date, more 
than 18,000 species of sponges were described, of which approximately 8,800 are considered valid, most occurring in marine environments, with about $1 \%$ being found in freshwater habitats, ${ }^{12}$ but as many as twice that number are thought to exist. They are sessile invertebrates with a wide variety of colors, shapes and consistencies that have developed efficient defense mechanisms against predators.

Marine sponges are filter feeding porous animals and usually harbor a remarkable array of microorganisms in their mesohyl tissues as transient and resident endosymbionts. The marine sponge-microbial interactions are highly complex and, in some cases, the relationships are thought to be truly symbiotic or mutualistic rather than temporary associations resulting from sponge filter-feeding activity. The marine sponge-associated microorganisms are a fascinating source for various biomolecules that are of potential interest to several biotechnological industries. ${ }^{13}$

Cliona varians (Dushassaing \& Michelotti, 1864) is a species of encrusting and excavating demosponge belonging to the family Clionaidae. It is found in shallow water in the Caribbean Sea and its range extends from Cuba and Mexico south to Venezuela and Brazil. It usually grows on massive corals, covering its surface, but is sometimes found on some other calcareous substrate such as mollusk shells, crustacean carapaces or limestone rocks. It can form thick encrustations that may cover several square meters of substratum. Oscules are relatively large (10 to $30 \mathrm{~mm}$ wide), paler and slightly elevated, surrounded by projecting rims or small raised papillae 2 to $5 \mathrm{~mm}$ wide. The color is usually dull orange to tan or brownish. ${ }^{14}$

Literature reports that marine-derived organisms are sources of diverse enzymes suitable for biotransformation or biocatalytic reactions of organic compounds. ${ }^{15}$ In addition, several marine sponge-derived fungi have been applied in the bioreduction of iodoacetophenones, ${ }^{16}$ azido-ketones ${ }^{17}$ and isatin. ${ }^{18}$ However, to date, there is no report about the use of marine sponge's tissue in biotransformation reactions.

Concerning to the biotechnological properties of Cliona spp., methods of sponge cell culture for the production of biologically active metabolites are nowadays developed using primmorphs, three-dimensional aggregates comprising proliferating and differentiating sponge cells, which can be maintained for long periods. The primmorphs have been generated from a wide range of sponges, including Cliona celata Grant, $1826 .{ }^{19}$ In the coming years, it should become clear whether primmorphs can be scaled up sufficiently to overcome the supply problem for many promising drug leads. ${ }^{20}$

As a part of our ongoing project in the application of novel biocatalysts from the Brazilian biodiversity, ${ }^{7}$ herein we report an investigation of the whole marine sponge $C$. varians as reducing agent of $\alpha$-keto esters and isatin ( $1 H$-indole2,3-dione) (1) to the corresponding chiral alcohols.

\section{Experimental}

Isatin 1, ethyl pyruvate (2), $\alpha$-ketoglutaric acid (6), D-maltose, D-fructose, L-aspartate and $\mathrm{NaBH}_{4}$ were purchased from Aldrich Chemical Co., Milwaukee, WI, USA. D-Glucose and glycine were purchased from Merck, Darmstadt, Germany. L-Alanine and L-glutamate were purchased from Vetec, São Paulo, Brazil. All reagents were used without further purification. Alcohols were distilled immediately prior to use. The reactions involving anhydrous solvents were carried out under argon atmosphere. Column chromatography was performed using silica gel (70-230 Mesh from Acros) and reactions were monitored by thin-layer chromatography (TLC) Silica TLC plates (Macherey-Nagel, Germany).

${ }^{1} \mathrm{H}$ nuclear magnetic resonance (NMR) spectra were recorded in $\mathrm{CDCl}_{3}$ solution at 500 or $200 \mathrm{MHz}$ and ${ }^{13} \mathrm{C}$ NMR spectra in $\mathrm{CDCl}_{3}$ solution at 125 or $50 \mathrm{MHz}$ on a Varian equipment mod. Inova 500 and on a Bruker equipment mod. DPX 200. Chemical shifts, given on the $\delta$ scale, were referenced to the residual, undeuterated portion using of the deuterated $\mathrm{CDCl}_{3}$ solvent $\left(\delta_{\mathrm{H}} 7.27\right)$ in relation to tetramethylsilane (TMS). Infrared (IR) spectra were recorded on a Shimadzu FTIR spectrophotometer mod. IR Affinity-1S. Optical rotations were measured at $25^{\circ} \mathrm{C}$ in a PerkinElmer 343 Polarimeter at $589 \mathrm{~nm}$ (sodium $\mathrm{D}$ line). The conversions and enantiomeric excess (ee) of $\alpha$-hydroxy esters $\mathbf{2 a - 5 a}$ and 3-hydroxyindolin2-one (1a) were determined by gas chromatography (GC) analysis using an Agilent Technologies equipment model 7820A, with flame ionization detector (FID), employing Agilent Cyclosil-B Capillary Column 30\% heptakis(2,3-di-O-methyl-6-O-t-butyldimethylsilyl)- $\beta$-cyclodextrin $(30 \mathrm{~m} \times 0.25 \mathrm{~mm} \times 0.25 \mathrm{~mm})$ as stationary phases. Nitrogen was used as the carrier gas, flow rate of $1.18 \mathrm{~mL} \mathrm{~min}^{-1}$ in split mode; the injector temperature and detector temperature were set at $220{ }^{\circ} \mathrm{C}$; the column temperature was programmed at $80{ }^{\circ} \mathrm{C}$ for $10 \mathrm{~min}, 2^{\circ} \mathrm{C} \mathrm{min}-1$ from 80 to $200^{\circ} \mathrm{C}$ for $10 \mathrm{~min}$.

\section{Biocatalysts}

Specimens of the marine sponge Cliona varians were collected in tide pools (0-0.5 m depth) at Praia do Forte Beach, Mata de São João (12³3'50”S/37'59'36”W) at coastline of Bahia (Northeastern Brazil). The species C. varians was identified by marine biologist Dr Carla 
Menegola. Voucher specimen (No. 4039, 4040 and 4032) has been deposited at the Zoology Museum of the Biology Department, Federal University of Bahia, Salvador, Brazil. The collect was authorized by Environmental Minister (permanent license SISBIO-ICMBio-MMA No. 11793-3). After the collection, the fresh sponges were transported in a thermal box at $4{ }^{\circ} \mathrm{C}$, and then washed exhaustively with sea water and frozen at $-18{ }^{\circ} \mathrm{C}$ until use. All sponges were collected on sunny days, when ocean water temperature was between 25 and $27^{\circ} \mathrm{C}$.

\section{Synthesis of $\alpha$-keto esters}

To a solution of $\alpha$-ketoglutaric acid (6) (3.3 mmol, $500 \mathrm{mg}$ ) in freshly distilled dry alcohol (methanol, ethanol or isopropanol) $(10 \mathrm{~mL})$ at room temperature, it was added $p$-toluenesulfonic acid (PTSA) (0.4 mmol, $65 \mathrm{mg}$ ). The mixture was refluxed $24 \mathrm{~h}$ and sequentially $\mathrm{NaHCO}_{3}$ (0.8 mmol, $70 \mathrm{mg}$ ) was added. After stirring $30 \mathrm{~min}$ at room temperature, the solvent was removed in vacuo and the crude mixture was diluted with ethyl acetate $(10 \mathrm{~mL})$, dried over $\mathrm{MgSO}_{4}$ and concentrated under reduced pressure. Silica gel column chromatography $(50 \%$ EtOAc in hexanes, $\mathrm{v} / \mathrm{v}$ ) of the crude product afforded the respective ester as a colorless oil.

\section{Dimethyl 2-oxoglutarate (3)}

Yield 78\%; ${ }^{1} \mathrm{H}$ NMR $\left(\mathrm{CDCl}_{3}, 500 \mathrm{MHz}\right) \delta 2.69(\mathrm{t}$, $J 5.9 \mathrm{~Hz}, 2 \mathrm{H}), 3.17$ (t, J $5.9 \mathrm{~Hz}, 2 \mathrm{H}), 3.69$ (s, 3H), 3.89 $(\mathrm{s}, 3 \mathrm{H}) ;{ }^{13} \mathrm{C} \mathrm{NMR}\left(\mathrm{CDCl}_{3}, 125 \mathrm{MHz}\right) \delta 27.4,34.2,51.9$, 53.0, 160.9, 172.4, 192.2; IR (film) $v / \mathrm{cm}^{-1} 3005,2958$, $1782,1732,1438,1168,1083$; GC (FID) $\mathrm{t}_{\mathrm{R}}: 39.3 \mathrm{~min}$; TLC (EtOAc:hexane 1:1) Rf $=0.40$.

\section{Diethyl 2-oxoglutarate (4)}

Yield 76\%; ${ }^{1} \mathrm{H}$ NMR $\left(\mathrm{CDCl}_{3}, 200 \mathrm{MHz}\right) \delta 1.22(\mathrm{t}$, $J 7.0 \mathrm{~Hz}, 3 \mathrm{H}), 1.34(\mathrm{t}, J 7.0 \mathrm{~Hz}, 3 \mathrm{H}), 2.63(\mathrm{t}, J 6.5 \mathrm{~Hz}$, $2 \mathrm{H}), 3.12$ (t, J 6.5 Hz, 2H), 4.10 (q, J 7.0 Hz, 2H), 4.29 $(\mathrm{q}, J 7.0 \mathrm{~Hz}, 2 \mathrm{H}) ;{ }^{13} \mathrm{C} \mathrm{NMR}\left(\mathrm{CDCl}_{3}, 50 \mathrm{MHz}\right) \delta 13.9$, 14.1, 27.7, 34.1, 60.8, 62.5, 160.5, 171.9, 192.7; IR (film) $\mathrm{v} / \mathrm{cm}^{-1} 2983,1737,1255,1082$; GC (FID) $\mathrm{t}_{\mathrm{R}}: 46.9 \mathrm{~min}$; TLC (EtOAc:hexane 1:1) Rf $=0.60$.

\section{Diisopropyl 2-oxoglutarate (5)}

Yield 70\%; ${ }^{1} \mathrm{H}$ NMR $\left(\mathrm{CDCl}_{3}, 200 \mathrm{MHz}\right) \delta 1.23(\mathrm{~d}$, $J 6.2 \mathrm{~Hz}, 6 \mathrm{H}), 1.35$ (d, J $6.2 \mathrm{~Hz}, 6 \mathrm{H}), 2.63(\mathrm{t}, J 5.4 \mathrm{~Hz}$, 2H), 3.13 (t, J $5.4 \mathrm{~Hz}, 2 \mathrm{H}$ ), 5.00 (hept., $J 6.2 \mathrm{~Hz}, 1 \mathrm{H}$ ), 5.15 (hept., $J 6.2 \mathrm{~Hz}, 1 \mathrm{H}) ;{ }^{13} \mathrm{C} \mathrm{NMR}\left(\mathrm{CDCl}_{3}, 50 \mathrm{MHz}\right) \delta$ 21.6, 21.8, 28.0, 34.2, 68.3, 70.8, 160.2, 171.5, 193.1; IR (film) $v / \mathrm{cm}^{-1}$ 2983, 1730, 1469, 1377, 1215, 1078, 758; GC (FID) $\mathrm{t}_{\mathrm{R}}: 41.5 \mathrm{~min}$; TLC (EtOAc:hexane 1:1) $\mathrm{Rf}=0.70$.
Synthesis of standard racemic dimethyl 2-hydroxyglutarate $(3 a)^{21}$

To a solution of dimethyl 2-oxoglutarate (3) (100 mg, $0.57 \mathrm{mmol})$ in $\mathrm{MeOH}(4.0 \mathrm{~mL})$ at $0{ }^{\circ} \mathrm{C}$, under argon atmosphere, it was added $\mathrm{NaBH}_{4}$ (1.5 eq., $0.86 \mathrm{mmol}$ ). The mixture was stirred $24 \mathrm{~h}$ at room temperature and citric acid was added until the $\mathrm{pH}$ reaches 5-6. Then, silica gel $(150 \mathrm{mg})$ was added to de reaction mixture and the solvent was evaporated under reduced pressure. The residue was purified by silica gel column chromatography (EtOAc:hexane 1:1) to afford dimethyl 2-hydroxyglutarate (3a) $(79.2 \mathrm{mg}, 0.45 \mathrm{mmol}$ ) as a colorless oil, in $78 \%$ yield; ${ }^{1} \mathrm{H} \mathrm{NMR}\left(\mathrm{CDCl}_{3}, 500 \mathrm{MHz}\right) \delta 1.94$ (dtd, $J$ 14.3, 8.1 and $6.2 \mathrm{~Hz}, 1 \mathrm{H}$ ), 2.15 (dddd, $J 14.3,8.1,7.3,4.2 \mathrm{~Hz}, 1 \mathrm{H}$ ), 2.44 (ddd, $J 16.6,8.1,6.2 \mathrm{~Hz}, 1 \mathrm{H}), 2.53$ (ddd, $J 16.6,8.1,7.3 \mathrm{~Hz}$, 1H), 2.96 (br s, 1H), 3.69 (s, 3H), 3.80 (s, 3H), 4.25 (dd, $J$ 8.1, 4.2 Hz, $1 \mathrm{H}) ;{ }^{13} \mathrm{C} \mathrm{NMR}\left(\mathrm{CDCl}_{3}, 125 \mathrm{MHz}\right) \delta 29.2$, 29.5, 51.8, 52.7, 69.5, 173.6, 175.1; IR (film) $\mathrm{v} / \mathrm{cm}^{-1} 3483$, 2954, 1739, 1438, 1261, 1107; GC (FID) $\mathrm{t}_{\mathrm{R}}(S): 35.3 \mathrm{~min}$ and $\mathrm{t}_{\mathrm{R}}(R): 35.8 \mathrm{~min}$; TLC (EtOAc:hexane 1:1) $\mathrm{Rf}=0.30$.

General procedure for the preparation of standard racemic diethyl 2-hydroxyglutarate $(\mathbf{4 a})$ and diisopropyl 2-hydroxyglutarate $(\mathbf{5 a})^{21}$

To a solution of 2-oxoglutarate ester $(0.6 \mathrm{mmol})$ in tetrahydrofuran (THF) $(20.0 \mathrm{~mL})$ at $0{ }^{\circ} \mathrm{C}$, under argon atmosphere was added $\mathrm{NaBH}_{4}$ (2.0 eq., $1.2 \mathrm{mmol}$ ). The mixture was stirred $24 \mathrm{~h}$ at room temperature and citric acid was added until the $\mathrm{pH}$ reaches 5-6. Then, silica gel $(250 \mathrm{mg})$ was added to the reaction mixture and the solvent was evaporated under reduced pressure. The residue was purified by silica gel column chromatography (EtOAc:hexane 1:1) to afford the respective $\alpha$-hydroxy esters as a colorless oil.

\section{Diethyl 2-hydroxyglutarate (4a)}

Yield 33\%; ${ }^{1} \mathrm{H} \mathrm{NMR}\left(\mathrm{CDCl}_{3}, 200 \mathrm{MHz}\right) \delta 1.23(\mathrm{t}$, $J 7.7 \mathrm{~Hz}, 3 \mathrm{H}), 1.27$ (t, J 7.7 Hz, 3H), 1.84-1.98 (m, 1H), 2.06-2.22 (m, 1H), 2.41-2.49 (m, 2H), 3.10 (br s, 1H), 4.05-4.27 (m, 5H); ${ }^{13} \mathrm{C} \mathrm{NMR}\left(\mathrm{CDCl}_{3}, 50 \mathrm{MHz}\right) \delta 14.1,29.3$, 29.7, 60.5, 61.8, 69.5, 173.1, 174.6; IR (film) $v / \mathrm{cm}^{-1} 3500$, 2954, 1732, 1440, 1215, 1107; GC (FID) $\mathrm{t}_{\mathrm{R}}(R): 41.3 \mathrm{~min}$ and $t_{\mathrm{R}}(S): 41.8 \mathrm{~min}$; TLC (EtOAc:hexane 1:1) $\mathrm{Rf}=0.40$.

\section{Diisopropyl 2-hydroxyglutarate (5a)}

Yield 54\%; ${ }^{1} \mathrm{H} \mathrm{NMR}\left(\mathrm{CDCl}_{3}, 200 \mathrm{MHz}\right) \delta 1.21(\mathrm{~d}$, $J 6.3 \mathrm{~Hz}, 6 \mathrm{H}), 1.26$ (d, J $6.3 \mathrm{~Hz}, 6 \mathrm{H}), 1.79-1.97$ (m, 1H), 2.05-2.21 (m, 1H), 2.37-2.51 (m, 2H), 3.00 (br s, 1H), 4.16 (dd, J 3.9, $7.7 \mathrm{~Hz}, 1 \mathrm{H}), 4.93-5.14$ (m, 2H); ${ }^{13} \mathrm{C} \mathrm{NMR}$ $\left(\mathrm{CDCl}_{3}, 50 \mathrm{MHz}\right) \delta 21.8,29.4,30.1,67.8,69.6,69.7,172.7$, 
174.2; IR (film) $v / \mathrm{cm}^{-1} 3483,2954,1739,1438,1281$, 1107; GC (FID) $\mathrm{t}_{\mathrm{R}}(R): 37.6$ min and $\mathrm{t}_{\mathrm{R}}(S): 37.9$ min; TLC (EtOAc:hexane 1:1): $\mathrm{Rf}=0.50$.

\section{Synthesis of standard racemic 3-hydroxyindolin-2-one (1a) $)^{22}$}

To a solution of $\mathrm{NaBH}_{4}(3 \mathrm{mmol}, 1.5 \mathrm{eq} ., 112.4 \mathrm{mg})$ in $12 \mathrm{~mL}$ of $1: 1 \mathrm{CH}_{2} \mathrm{Cl}_{2}: \mathrm{EtOH}$, at $0{ }^{\circ} \mathrm{C}$, under argon atmosphere, was added a solution of commercially available isatin 1 (2.0 mmol, $294 \mathrm{mg}$ ) in $8 \mathrm{~mL}$ of $1: 1 \mathrm{CH}_{2} \mathrm{Cl}_{2}: \mathrm{EtOH}$. The mixture was stirred during $5 \mathrm{~min}$ at $0{ }^{\circ} \mathrm{C}$ and then $2.0 \mathrm{~mL}$ of water was added. Sequentially, the mixture was stirred $10 \mathrm{~min}$ at room temperature and it was extracted with $\mathrm{CH}_{2} \mathrm{Cl}_{2}(3 \times 10 \mathrm{~mL})$. The organic phase was washed with brine $(10 \mathrm{~mL})$, dried over $\mathrm{MgSO}_{4}$, filtered and concentrated. The crude product was purified by recrystallization (EtOAc/hexane) to afford 3-hydroxyindolin-2-one (1a) (194 mg, $1.3 \mathrm{mmol}$ ) in 65\% yield, as a beige solid; ${ }^{1} \mathrm{H}$ NMR (DMSO- $\left.d_{6}, 500 \mathrm{MHz}\right) \delta 3.14$ (br s, 1H), 4.81 (s, 1H), 6.78 $(\mathrm{d}, J 7.8 \mathrm{~Hz}, 1 \mathrm{H}), 6.95(\mathrm{t}, J 7.5 \mathrm{~Hz}, 1 \mathrm{H}), 7.20(\mathrm{t}, J 7.8 \mathrm{~Hz}$, $1 \mathrm{H}), 7.27(\mathrm{~d}, J 7.5 \mathrm{~Hz}, 1 \mathrm{H}), 10.21(\mathrm{~s}, 1 \mathrm{H}) ;{ }^{13} \mathrm{C} \mathrm{NMR}$ $\left(\mathrm{DMSO}-d_{6}, 125 \mathrm{MHz}\right) \delta 69.6,109.9,121.9,125.2,129.3$, 129.7, 142.6, 178.3; IR (film) v / $\mathrm{cm}^{-1} 3379,2926,2341$, 1728, 1618; GC (FID) the column did not separate the enantiomers, $\mathrm{t}_{\mathrm{R}}$ : $71.4 \mathrm{~min}$; GC (FID) isatin: $\mathrm{t}_{\mathrm{R}}: 73.3 \mathrm{~min}$; TLC (EtOAc:hexane 1:1) Rf =0.20.

Synthesis of standard racemic ethyl 2-hydroxypropanoate $(2 a)^{21}$

To a solution of commercially available ethyl pyruvate (2) $(100 \mathrm{mg}, 0.87 \mathrm{mmol})$ in EtOAc $(4.0 \mathrm{~mL})$ at $0{ }^{\circ} \mathrm{C}$, under argon atmosphere, was added $\mathrm{NaBH}_{4}$ (0.5 eq., $16.7 \mathrm{mg}$, $0.44 \mathrm{mmol})$. The mixture was stirred $24 \mathrm{~h}$ at room temperature and was added acetic acid until the $\mathrm{pH}$ reaches 4-5. Then, the solvent was evaporated under reduced pressure to afford ethyl 2-hydroxypropanoate (2a) $(44.9 \mathrm{mg}$, $0.38 \mathrm{mmol}$ ) as a colorless oil in $46 \%$ yield; IR (film) $v / \mathrm{cm}^{-1}$ 3441, 2985, 2939, 1732, 1215, 1134, 428; GC $\left(\right.$ FID) $\mathrm{t}_{\mathrm{R}}(S): 28.8 \mathrm{~min}$ and $\mathrm{t}_{\mathrm{R}}(R): 29.3 \mathrm{~min}$; GC (FID) ethyl pyruvate $t_{R}: 30.2$ min; TLC (EtOAc:hexane $\left.1: 1\right) \mathrm{Rf}=0.35$.

\section{Bioreduction of substrates}

Bioreduction reactions were performed using various additives (e.g., sugars such as sucrose, D-glucose, D-maltose, and D-fructose or amino acids such as L-alanine, glycine, L-glutamate, and L-aspartate).

The specimens were rinsed with aqueous $0.85 \%(\mathrm{v} / \mathrm{v})$ sea salt solution and cut into small pieces (approx. $1 \mathrm{~cm}$ long slice) with a sterile knife. In separate experiments, substrates 1-5 $(1.15 \mathrm{mmol})$ and additive $(38.0 \mathrm{mmol})$ were individually added to a suspension of the freshly pieces of sponges $(40 \mathrm{~g})$ in aqueous $0.85 \%(\mathrm{v} / \mathrm{v})$ sea salt solution $(120 \mathrm{~mL})$. The mixtures were incubated in a shaker (180 rpm) at $25^{\circ} \mathrm{C}$ for 3 days, when sugars were used as additives, and 5 days when amino acids were used. The reaction process was monitored by TLC. Each individual suspension was filtered, and the residue was washed with water. The aqueous solutions were then extracted with EtOAc $(3 \times 30 \mathrm{~mL})$, and the organic soluble fractions were dried with $\mathrm{MgSO}_{4}$ and evaporated under reduced pressure. The residues were filtered on a short silica gel column, using $\mathrm{CHCl}_{3}$ as eluent, to afford the reduced products. Conversions and enantiomeric excess were quantified employing chiral GC analyses. The stereochemistry of the major enantiomer was determined by measuring the specific rotation of the mixture obtained after the biotransformation step and comparing it with the specific rotation value reported in literature.

(-)-(S)-Dimethyl 2-hydroxyglutarate (3a)

L-Aspartate (additive): 65\% conversion; $16 \%$ ee $(S)$; $[\alpha]_{\mathrm{D}}{ }^{25}-1.0(c 0.38, \mathrm{MeOH})$; Lit. $(S):[\alpha]_{\mathrm{D}}{ }^{25}-5.2$ (c 0.38 , $\mathrm{MeOH}){ }^{23}$

\section{(+)-(R)-Dimethyl 2-hydroxyglutarate (3a)}

Sucrose (additive): $70 \%$ conversion; $28 \%$ ee $(R)$; $[\alpha]_{\mathrm{D}}^{25}+1.5(c 0.38, \mathrm{MeOH})$. D-Fructose (additive): $46 \%$ conversion; $12 \%$ ee $(R) ;[\alpha]_{\mathrm{D}}^{25}+1.0(c 0.38, \mathrm{MeOH})$.

\section{(-)-(S)-Diethyl 2-hydroxyglutarate (4a)}

Sucrose (additive): $20 \%$ conversion; $24 \%$ ee $(S) ; 11 \%$ yield; $[\alpha]_{\mathrm{D}}{ }^{25}-1.0(c 0.45, \mathrm{MeOH})$. L-Aspartate (additive): $40 \%$ conversion; $38 \%$ ee $(S) ; 26 \%$ yield; $[\alpha]_{\mathrm{D}}{ }^{25}-1.5(c 0.45$, $\mathrm{MeOH})$; Lit. $(S):[\alpha]_{\mathrm{D}}{ }^{25}-4.1(c 0.45, \mathrm{MeOH}){ }^{23}$

\section{(+)-(R)-Diethyl 2-hydroxyglutarate (4a)}

D-Fructose (additive): $35 \%$ conversion; $60 \%$ ee $(R)$; $18 \%$ yield; $[\alpha]_{\mathrm{D}}^{25}+2.2(c 0.45, \mathrm{MeOH})$.

\section{(-)-(S)-Diisopropyl 2-hydroxyglutarate (5a)}

Sucrose (additive): $81 \%$ conversion; $47 \%$ ee $(S) ; 30 \%$ yield; $[\alpha]_{\mathrm{D}}^{25}-1.6(c 0.88, \mathrm{MeOH})$. D-Fructose (additive): $68 \%$ conversion; $75 \%$ ee $(S) ; 45 \%$ yield; $[\alpha]_{\mathrm{D}}{ }^{25}-2.5(c 0.88$, $\mathrm{MeOH})$; Lit. $(S):[\alpha]_{\mathrm{D}}{ }^{25}-3.5(c 0.88, \mathrm{MeOH}){ }^{23}$

\section{(R)-3-Hydroxyindolin-2-one (1a)}

D-Fructose (additive): $90 \%$ conversion; 44\% ee $(R)$; $42 \%$ yield; $[\alpha]_{\mathrm{D}}{ }^{25}+3.1(c 1.00, \mathrm{MeOH}) ;$ Lit. $(R):[\alpha]_{\mathrm{D}}{ }^{25}+7.0$ $(c 1.00 ; \mathrm{MeOH}){ }^{24}$

(-)-(S)-3-Hydroxyindolin-2-one (1a)

Absence of additive: $23 \%$ conversion; $71 \%$ ee $(S) ; 15 \%$ 
yield; $[\alpha]_{D}{ }^{25}-5.0(c 1.00, \mathrm{MeOH})$. D-Glucose (additive): $85 \%$ conversion; $74 \%$ ee $(S)$; $46 \%$ yield; $[\alpha]_{\mathrm{D}}^{25}-5.2(c 1.00$, $\mathrm{MeOH}$ ). D-Maltose (additive): $90 \%$ convrsion; 60\% ee (S); $45 \%$ yield; $[\alpha]_{\mathrm{D}}{ }^{25}-4.2(c 1.00, \mathrm{MeOH})$.

\section{(-)-(S)-2-Hydroxypropanoate (2a)}

L-Glutamate (additive): $19 \%$ conversion; $70 \%$ ee; $10 \%$ yield; $[\alpha]_{D}{ }^{25}-10.4\left(c 2.0, \mathrm{CHCl}_{3}\right)$. L-Aspartate (additive): $20 \%$ conversion; $70 \%$ ee; $10 \%$ yield; $[\alpha]_{\mathrm{D}}^{25}-10.2$ (c 2.0, $\mathrm{CHCl}_{3}$ ). Sucrose (additive): $48 \%$ conversion; $84 \%$ ee; $37 \%$ yield; $[\alpha]_{\mathrm{D}}^{25}-12.5\left(\right.$ c 2.0, $\left.\mathrm{CHCl}_{3}\right)$. D-Glucose (additive): $58 \%$ conversion; $72 \%$ ee; $49 \%$ yield; $[\alpha]_{\mathrm{D}}{ }^{25}-10.6$ (c 2.0, $\mathrm{CHCl}_{3}$ ). D-Fructose (additive): 74\% conversion; $54 \% \mathrm{ee}$; $50 \%$ yield; $[\alpha]_{\mathrm{D}}{ }^{25}-8.0\left(c 2.0, \mathrm{CHCl}_{3}\right)$. Lit. $(S)$ : $[\alpha]_{\mathrm{D}}{ }^{25}-15$ (c 2.0, $\left.\mathrm{CHCl}_{3}\right)^{25}$

\section{Results and Discussion}

\section{Choose of substrates}

Enantiomerically pure $\alpha$-hydroxy esters are very important chiral building blocks for the synthesis of a variety of natural products and biologically active molecules. ${ }^{26}$ Although there are several reports available in the literature dealing with stereoselective reduction of ketones and $\beta$-keto esters mediated by biocatalysis, the bioreduction of $\alpha$-keto esters is less common. Chiral 3-hydroxyindolin-2-one (1a) is a product of the enantioselective reduction of isatin $\mathbf{1}$ and showed pharmacological potential to antiallergic, anti-inflammatory and anticancer activities. ${ }^{27}$ However, few studies in the literature have focused on the biotransformation of isatin derivatives by whole cells. ${ }^{28}$

The structure of the substrate is a determining factor for the stereochemical course of bioreduction reactions. ${ }^{29}$ The choice of structures was made in order to verify the influence of the relative steric volumes of the alkoxy groups of 2-oxoglutarate, compared with isatin $\mathbf{1}$ and ethyl pyruvate (2). The $\alpha$-keto esters choices as substrate were dimethyl-2-oxoglutarate (3), diethyl-2-oxoglutarate (4) and diisopropyl 2-oxoglutarate (5).

\section{Synthesis of substrates}

Isatin 1 and ethyl pyruvate (2) employed were commercially available. Dimethyl 2-oxoglutarate (3), diethyl 2-oxoglutarate (4), diisopropyl 2-oxoglutarate (5) were obtained in 78,76 and $70 \%$ yields, respectively, from the esterification of $\alpha$-ketoglutaric acid (6) with the corresponding alcohol, in the presence of PTSA (Scheme 1).

Bioreductions of isatin 1 and $\alpha$-keto esters $2-5$ by marine sponge $C$. varians

Stereoselectivity of microbe-catalyzed reduction of keto esters can be controlled by the addition of additives in the reaction systems. ${ }^{30}$ Furthermore, the conversion ratios of $\alpha$-keto esters to the corresponding $\alpha$-hydroxy esters, using biotransformation, were increased by addition of sugars or amino acids into the reaction mixture as an additive. ${ }^{31}$ In recent years, the effect of additives on the reduction of $\alpha$-keto esters, using marine actinomycetes, were investigated. Among various additives (e.g., sugars or amino acids), the introduction of L-glutamate or sucrose remarkably increased the conversion ratio of the reduction. ${ }^{32}$

With this goal in mind, dimethyl 2-oxoglutarate (3) was chosen as a model substrate to explore the effect of additives on conversion and stereoselectivity of sponge reduction. The first series of bioreductions was carried out at $25{ }^{\circ} \mathrm{C}$ and the effect of additives on the reduction of $\mathbf{3}$, using marine sponge $C$. varians, was investigated. Experiments were performed in triplicate and the results are presented in Table 1.

It was found that $C$. varians did not reveal a capacity for the bioreduction of $\mathbf{3}$ in the absence of additive (Table 1, entry 1), whereas no reaction was observed in the presence of L-alanine and glycine (Table 1, entries 2 and 3). L-Aspartate, sucrose and D-fructose showed better conversion to $\alpha$-hydroxy ester $\mathbf{3 a}$, but low selectivities (12-28\%) (Table 1, entries 4, 6 and 8). L-Glutamate, D-glucose and D-maltose showed low conversions to $\mathbf{3 a}$

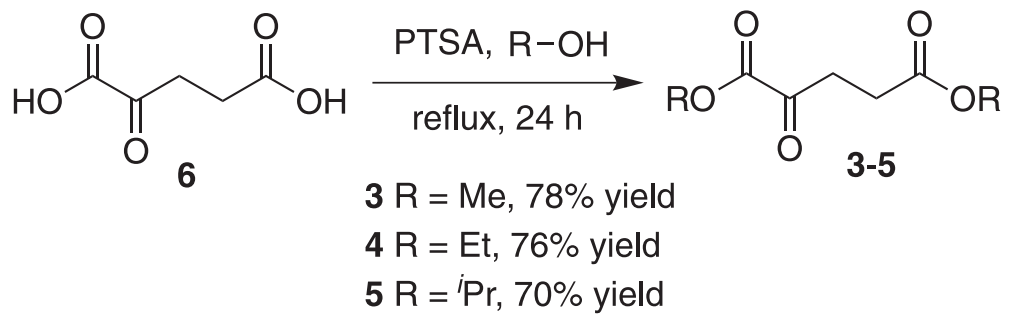

Scheme 1. Synthesis of $\alpha$-keto esters 3-5. 
Table 1. Bioreduction reactions of dimethyl 2-oxoglutarate (3) by C. varians<smiles>COC(=O)CCC(=O)C(=O)OC</smiles>

\begin{tabular}{lccc}
\hline entry & Additive & Conversion $^{\mathbf{a}} / \%$ & $e e^{\mathbf{a}} / \%$ \\
\hline 1 & none & - & - \\
2 & L-alanine & - & - \\
3 & glycine & - & $16(S)-\mathbf{3 a}$ \\
4 & L-aspartate & 65 & $42(S)-\mathbf{3 a}$ \\
5 & L-glutamate & 10 & $28(R)-\mathbf{3 a}$ \\
6 & sucrose & 70 & $8(R)-\mathbf{3 a}$ \\
7 & D-glucose & 20 & $12(R)-\mathbf{3 a}$ \\
8 & D-fructose & 46 & $20(S)-\mathbf{3 a}$ \\
9 & D-maltose & 20 &
\end{tabular}

${ }^{a}$ Conversion and enantiomeric excess (ee) were determined by chiral GC.

(Table 1, entries 5, 7 and 9). Depending on the additive employed, different enantiomerically enriched $\alpha$-hydroxy esters 3a were obtained. The addition of the additives L-aspartate, L-glutamate and D-maltose produce the $S$ enantiomer (Table 1, entries 4, 5 and 9), while the addition of the additives sucrose, D-glucose and D-fructose produce the $R$ isomer (Table 1, entries 6, 7 and 8). Therefore, their structures are not predictable via the empirical Prelog rule, ${ }^{33}$ which describes the stereoselectivity of the attack of the hydride ion to the carbonyl group. The configuration was dependent on the nature of the additive employed.

The mechanism underlying the increase in the conversion due to the addition of sugars or amino acids as additives to the reaction mixtures is not clear. It seems that the increase in the concentration of reduced nicotinamide-adenine dinucleotide (NADH or NADPH) due to the oxidative degradation of the additive by the enzymes present in the marine sponge would accelerate the stereoselective reduction of $\alpha$-keto esters to the corresponding optically pure alcohols. ${ }^{31}$

In order to expand the study to other $\alpha$-keto esters, it was performed a series of bioreductions employing diethyl 2-oxoglutarate 4 and diisopropyl 2-oxoglutarate $\mathbf{5}$ as substrates. L-Aspartate, sucrose and D-fructose were employed as additives for these studies. The obtained results are described in Table 2.

The products obtained through the use of L-aspartate and sucrose showed predominance of the $S$ configuration.

Table 2. Bioreduction reactions of $\alpha$-keto esters 4 and 5 by $C$. varians<smiles>[R]OC(=O)CCC(=O)C(=O)O</smiles>

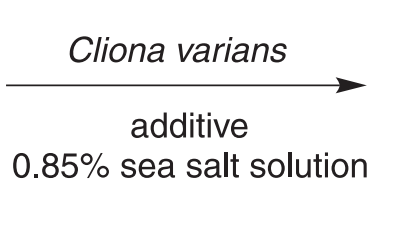<smiles>[R]C(=O)CCC(O)C(=O)O</smiles>

\begin{tabular}{lcccc}
\hline entry & $\mathrm{R}$ & Additive & Conversion $^{\mathrm{a}} / \%$ & $e e^{\mathrm{a}} / \%$ \\
\hline 1 & Et & sucrose & 25 & $24(S)-\mathbf{4 a}$ \\
2 & Et & D-fructose & 35 & $60(R)-\mathbf{4 a}$ \\
3 & Et & L-aspartate & 40 & $38(S)-\mathbf{4 a}$ \\
4 & $i \operatorname{Pr}$ & sucrose & 81 & $47(S)-\mathbf{5 a}$ \\
5 & ${ }^{i} \operatorname{Pr}$ & D-fructose & 70 & $75(S)-\mathbf{5 a}$ \\
6 & ${ }^{i} \operatorname{Pr}$ & L-aspartate & - & - \\
\hline
\end{tabular}

${ }^{a}$ Conversion and enantiomeric excess (ee) were determined by chiral GC. 
Only D-fructose was able to reduce the $\alpha$-keto ester 4 to corresponding alcohol $\mathbf{4 a}$ with $R$-configuration (Table 2 , entry 2). Unfortunately, the reduction of diethyl $\alpha$-keto ester 4 by $C$. varians, in the presence of sucrose, D-fructose and L-aspartate gave the corresponding $\alpha$-hydroxy ester $\mathbf{4 a}$ with low conversions (25-40\%) (Table 2, entries 1-3) and moderate $e e(60 \% R$-configuration). It is interesting to note that no reduction of diisopropyl $\alpha$-keto ester $\mathbf{5}$ in presence of L-aspartate (Table 2, entry 6) was observed, while sucrose and D-fructose gave the corresponding $\alpha$-hydroxy ester 5a with good conversions (70-81\%) and moderate to good selectivities (ee 47-75\%, Table 2, entries 4 and 5). The $(-)-(S)$-diisopropyl 2-hydroxyglutarate (5a), produced by bioreduction in the presence of D-fructose, was isolated by column chromatography with $45 \%$ yield and $75 \% e e$.

After these encouraging results, we decided to extend our studies toward the analysis of isatin $\mathbf{1}$ and ethyl pyruvate (2), in order to investigate the substrate specificity of marine sponge $C$. varians. The biorreduction reactions of ethyl pyruvate (2) were carried out at $25{ }^{\circ} \mathrm{C}$, the experiments were performed in triplicate and the results are presented in Table 3.

The use of L-aspartate, L-glutamate, sucrose, D-glucose and D-fructose additives led to the formation of $\mathbf{2 a}$ with predominance of the $S$-configuration. No reaction was observed in the presence of L-alanine, glycine and in the absence of additive (Table 3, entries 1-3). However, the low to moderate conversions did not improve by the addition of some additives such as L-glutamate, L-aspartate, sucrose and D-glucose (19-58\%) (Table 3, entries 4-7). Whereas, the reduction of ethyl pyruvate (2) by $C$. varians in presence of D-fructose gave the corresponding alcohol 2a with 78\%
Table 3. Bioreduction reactions of ethyl pyruvate (2) by $C$. varians

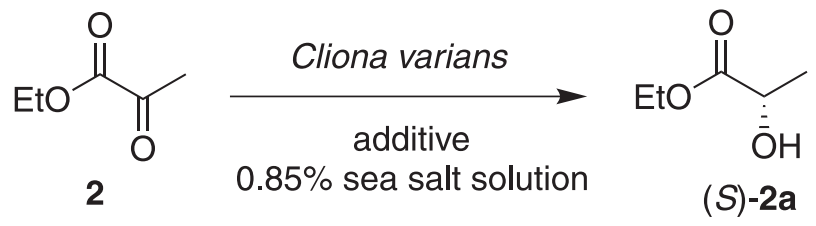

\begin{tabular}{lccc}
\hline entry & Additive & Conversion $^{\mathrm{a}} / \%$ & $e e^{\mathrm{a}} / \%$ \\
\hline 1 & none & 0 & - \\
2 & L-alanine & 0 & - \\
3 & glycine & 0 & - \\
4 & L-glutamate & 19 & $70(S)-\mathbf{2 a}$ \\
5 & L-aspartate & 20 & $70(S)-\mathbf{2 a}$ \\
6 & sucrose & 48 & $84(S)-\mathbf{2 a}$ \\
7 & D-glucose & 58 & $72(S)-\mathbf{2 a}$ \\
8 & D-fructose & 74 & $54(S)-\mathbf{2 a}$ \\
\hline
\end{tabular}

${ }^{\mathrm{a} C}$ Conversion and enantiomeric excess (ee) were determined by chiral GC.

conversion. On the other hand, the introduction of sucrose improved the stereoselectivity of the $\alpha$-hydroxy ester (S)-2a (84\% ee) (Table 3, entry 6), moreover the effects of other additives (L-glutamate, L-aspartate and D-glucose) gave goods stereoselectivities of the produced alcohol (70-72\% ee) (Table 3, entries 4, 5 and 7). The (-)-(S)-ethyl lactate (2a), produced in the presence of sucrose, was isolated by column chromatography with $37 \%$ yield and $84 \%$ ee.

The biorreduction reactions of isatin $\mathbf{1}$ were done at $25{ }^{\circ} \mathrm{C}$. The experiments were performed in triplicate and the results are presented in Table 4.

The products obtained through the use of sucrose, D-glucose and D-maltose showed predominance of the

Table 4. Bioreduction reactions of isatin $\mathbf{1}$ by $C$. varians

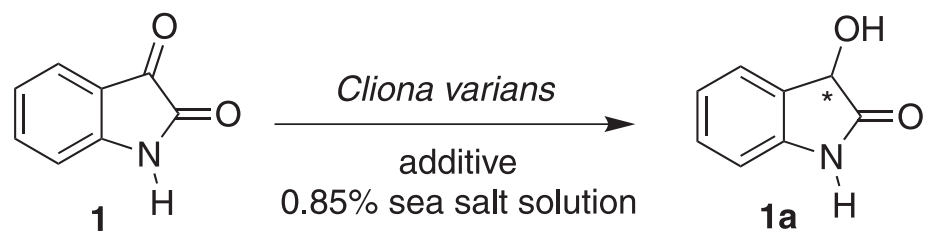

\begin{tabular}{lccc}
\hline entry & Additive & Conversion $^{\mathrm{a}} / \%$ & $e e^{\mathrm{b}} / \%$ \\
\hline 1 & none & 23 & $71(S)-\mathbf{1 a}$ \\
2 & L-alanine & - & - \\
3 & L-glutamate & - & - \\
4 & L-aspartate & - & - \\
5 & sucrose & 5 & $61(S)-\mathbf{1 a}$ \\
6 & D-glucose & 85 & $74(S)-\mathbf{1 a}$ \\
7 & D-fructose & 90 & $44(R)-\mathbf{1 a}$ \\
8 & D-maltose & 90 & $60(S)-\mathbf{1 a}$ \\
\hline
\end{tabular}

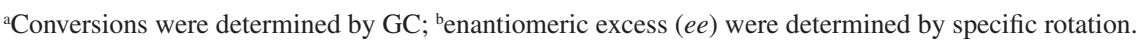


$S$-configuration. Only D-fructose was able to reduce the isatin $\mathbf{1}$ to corresponding $(R)$-(3)-hydroxyindolin2-one (1a), with $90 \%$ conversion and $44 \%$ ee (Table 4 , entry 7). As can be seen in Table 4, entry 1 , the marine sponge had natural activity for reducing isatin $\mathbf{1}$, and showed good stereoselectivity $(71 \% e e)$ in the absence of additive. In comparison with the reactions of $\alpha$-keto esters 2-3, the behavior was different because they were not reduced in the absence of additives. Furthermore, in the presence of sugars D-glucose and D-maltose, the reduction of isatin $\mathbf{1}$ afforded the corresponding (-)-(S)-(3)-hydroxyindolin-2-one 1a with high conversions (85-90\%) and good enantioselectivities (60-74\% ee). In the literature, whole cells of marine-derived fungi were used to reduce isatin $\mathbf{1}$ to $(-)-(S)-\mathbf{1 a} .{ }^{18}$ The best conversion was obtained by fungi Westerdykella sp. CBMAI 1679 (89\%), but with only $18 \% e e$, while best enantiomeric excess was obtained by fungi Aspergillus sydowii CBMAI 935 (66\% ee), but with only 9\% conversion. In our approach, the (-)-(S)-3-hydroxyindolin-2-one (1a), produced by marine sponge in the presence of D-glucose, was isolated by column chromatography with $46 \%$ yield and $74 \% e e$.

\section{Conclusions}

The results described in this paper demonstrate that the C. varians, a species of locally available marine sponge studied, has enzymatic systems with the required skill to reduce prochiral $\alpha$-keto esters $\mathbf{2 - 5}$ and isatin $\mathbf{1}$ to the corresponding chiral alcohols. As a result of this study, it is clear that an unexpected opportunity has arisen to be able to establish new applications for marine sponges, especially for those species which do not have any other reported practical utility. The encouraging results obtained here using whole marine sponge for biocatalysis may offer new strategies for the reduction of selected prochiral $\alpha$-keto esters and $\alpha$-keto lactam as a critical step in the synthetic organic pathway, specifically avoiding the use of costly and non-sustainable metal reducing agents and organic solvents that are commonly utilized in organic synthesis. In conclusion, four chiral $\alpha$-hydroxy esters and 3-hydroxyindolin-2-one (1a) were synthesized with satisfactory conversions $(70-81 \%)$ and medium to good enantiomeric excess (42-84\% ee), thus revealing the marine sponge $C$. varians to be a promising biocatalyst for the production of key intermediates. Further investigations are currently ongoing to try to expand the specificity and to explore novel catalytic activities of this new biocatalytic agent.

\section{Supplementary Information}

Supplementary data are available free of charge at http://jbcs.sbq.org.br as PDF file.

\section{Acknowledgments}

The authors are grateful to Brazilian Agencies CNPq (National Council for Scientific and Technological Development), FAPESB (Baiana Foundation for the Support of Scientific and Technological Development), and INCT E\&A (National Institute for Science and Technology for Energy and Environment) for financial support. The authors thank LABAREMN (UFBA) for conducting NMR spectra and Prof Gustavo Henrique Ribeiro Viana (UFSJ) for the support to synthesis of keto esters and NMR spectra. We are grateful to all the researchers and students who contributed collecting specimens: Rogerio Vianna (FURG), Tiago dos Anjos dos Santos, Daniele Menezes dos Santos, Myrla Josefa Santana Rocha and Danilo Pereira Pinto (UFBA). C. M. received grants and fellowship of FAPESB and CNPq (Project ESCUBRA-Sponges from the segment Cuba-Brasil).

\section{References}

1. Choi, J. M.; Han, S. S.; Kim, H. S.; Biotechnol. Adv. 2015, 33, 1443.

2. Bezborodov, A. M.; Zagustina, N. A.; Appl. Biochem. Microbiol. 2016, 52, 237.

3. Knowles, J. R.; Nature 1991, 350, 121.

4. Bommarius, A. S.; Ribel, B. R.; Biocatalysis: Fundamentals and Applications; Wiley-VCH: Weinheim, 2004.

5. Gašo-Sokač, D.; Nujić, M.; Bušić, V.; Habuda-Stanić, M.; Croat. J. Food Sci. Technol. 2014, 6, 51.

6. Mączka, W. K.; Mironowicz, A.; Tetrahedron: Asymmetry 2002, 13, 2299.

7. Victor, M. M.; Uchôa, J. E.; Riatto, V. B.; Ind. Crops Prod. 2017, 96, 126.

8. Machado, L. L.; Souza, J. S. N.; Mattos, M. C.; Sakata, S. K.; Cordell, G. A.; Lemos, T. L. G.; Phytochemistry 2006, 67, 1637.

9. Machado, L. L.; Monte, F. J. Q.; Oliveira, M. C. F.; Mattos, M. C.; Lemos, T. L. G.; Gotor-Fernandez, V.; Gonzalo, G.; Gotor, V.; J. Mol. Catal. B: Enzym. 2008, 54, 130.

10. Assunção, J. C. C.; Machado, L. L.; Lemos, T. L. G.; Cordell, G. A.; Monte, F. J. Q.; J. Mol. Catal. B: Enzym. 2008, 52, 194.

11. Leys, S. P.; Meech, R. W.; Can. J. Zool. 2006, 84, 288.

12. World Porifera Database, 2018. Available at: http://www. marinespecies.org/porifera, accessed in April 2018.

13. Sathiyanarayanan, G.; Saibaba, G.; Kiran, G. S.; Yang, Y. H.; Selvin, J.; Crit. Rev. Microbiol. 2017, 43, 294. 
14. Hechtel, G. J. In Zoogeography of Brazilian Demospongiae, vol. 1; Harrison F. W.; Cowden, R. R., eds.; Academic Press: New York, 1976; http://www.spongeguide.org, accessed in August 2018.

15. Birolli, W. G.; Ferreira, I. M.; Alvarenga, N.; Santos, D. A.; Matos, I. L.; Comasseto, J. V.; Porto, A. L. M.; Biotechnol. Adv. 2015, 33, 481.

16. Rocha, L. C.; Luiz, R. F.; Rosset, I. G.; Raminelli, C.; Seleghim, M. H. R.; Sette, L. D.; Porto, A. L. M.; Mar. Biotechnol. 2012, 14, 396.

17. Rocha, L. C.; Seleghim, M. H. R.; Comasseto, J. V.; Porto, A. L. M.; Mar. Biotechnol. 2015, 17, 736.

18. Birolli, W. G.; Ferrreira, I. M.; Jimenez, D. E. Q.; Silva, B. N. M.; Silva, B. V.; Pinto, A. C.; Porto, A. L. M.; J. Braz. Chem. Soc. 2017, 28, 1023.

19. Sipkema, D.; van Wielink, R.; van Lammeren, A. A.; Tramper, J.; Osinga, R.; Wijffels, R. H.; J. Biotechnol. 2003, 100, 127.

20. Taylor, M. W.; Radax, R.; Steger, D.; Wagner, M.; Microbiol. Mol. Biol. Rev. 2007, 71, 295.

21. Riatto, V. B.; Carneiro, M. N. M.; Carvalho, V. B.; Victor, M. M.; J. Braz. Chem. Soc. 2011, 22, 172.

22. Bergonzini, G.; Melchiorre, P.; Angew. Chem., Int. Ed. 2012, 51,971 .

23. Rustoy, E. M.; Pereyra, E. N.; Moreno, S.; Baldessari, A.; Tetrahedron: Asymmetry 2004, 15, 3763.

24. Hata, H.; Shimizu, S.; Hattori, S.; Yamada, H.; J. Org. Chem. 1990, 55, 4377.

25. Feenstra, R. W.; Stokkingreef, E. H. M.; Nivard, R. J. F.;
Ottenheijm, H. C. J.; Tetrahedron 1988, 44, 5583.

26. Hanessian, S.; Total Synthesis of Natural Products: The Chiron Approach; Pergamon Press: New York, 1983.

27. Cerchiaro, G.; Ferreira, A. M. C.; J. Braz. Chem. Soc. 2006, 17, 1473; Silva, B. V.; Ribeiro, N. M.; Vargas, M. D.; Lanznaster, M.; Carneiro, J. W. M.; Krogh, R.; Andricopulo, A. D.; Dias, L. C.; Pinto, A. C.; Dalton Trans. 2010, 39, 7338; Vine, K. L.; Matesic, L.; Locke, J. M.; Ranson, M.; Skropeta, D.; AntiCancer Agents Med. Chem. 2009, 9, 397.

28. Fukuoka, K.; Tanaka, K.; Ozeki, Y.; Kanaly, R. A.; Int. Biodeterior. Biodegrad. 2015, 97, 13; Qu, Y.; Xu, B.; Zhang, X.; Ma, Q.; Zhou, H.; Kong, C.; Zhang, Z.; Zhou, J.; Biochem. Eng. J. 2013, 72, 54.

29. Matsuda, T.; Yamanaka, R.; Nakamura, K.; Tetrahedron: Asymmetry 2009, 20, 513.

30. Kawai, Y.; Takanobe, K.; Ohno, A.; Bull. Chem. Soc. Jpn. 1995, 68, 285.

31. Ishihara, K.; Nishitani, M.; Yamaguchi, H.; Nakajima, N.; Ohshima, T.; Nakamura, K.; J. Ferment. Bioeng. 1997, 84, 268.

32. Ishihara, K.; Fujita, A.; Sakiyama, A.; Kobayashi, Y.; Hori, K.; Maruike, K.; Masuoka, N.; Nakajima, N.; Hamada, H.; Open J. Appl. Sci. 2013, 3, 116; Ishihara, K.; Nagai, H.; Takahashi, K.; Nishiyama, M.; Nakajima, N.; Biochem. Insights 2011, 4, 29.

33. Prelog, V.; J. Mol. Catal. 1976, 1, 159.

Submitted: May 15, 2018 Published online: August 27, 2018 